\title{
An Observation on the Students' Everyday Life Behaviors in College
}

\author{
English Class \\ Zhongmeng Chen \\ Foreign Languages School of Nanchang Normal University 330032 \\ Krispinchan@163.com
}

Keywords: College English; Class; Everyday Life Behaviors; Observation

\begin{abstract}
Classroom is a power territorial field with teacher and platform as the power sources. Teacher acts not only as the authority of knowledge imparting, but as the keeper and coordinator of the classroom orders. However, even under the surveillance of the teacher, everyday life behaviors manifest themselves in the following ways: spatially, they choose their own seats; temporally, they bargain with teacher and replace their behaviors etc. Such everyday life behaviors cause immense negative impacts: teachers' classroom emotion, the waste of teaching resources and pollution of the classroom.
\end{abstract}

\section{Introduction}

As a teacher of college English in Nanchang Teachers University, I am engaged in teaching about 60 students majored in arts and design in a big classroom of about 100 seats. In class, students have been showing everyday life behaviors instead of learning activities. However, I can't force them focus their attentions to English learning. For one thing, they are very poor in English with most of them less than 80 points in Gaokao English exam; for another thing, they are too many to care about all because a class is made up by two small classes (totally more than 60 students). It is a very difficult matter to organize them into an effective way of English learning. Such a case occurs not just to my English teaching class. In my hidden observations and participatory observations, the situation is quite common in other college English classes. To be specific, my photos and videos (Dec. $8^{\text {th }} 2015$ ) can show clearly students' everyday life behaviors of students majored in arts and design as well as the forbidden posters for preventing students from carrying breakfast or junk food into classrooms.

The display of students' everyday life behaviors in college English class can be described in terms of space, time and influences.

\section{Spatial Shows}

College students choose their own seats on their own instead of teachers' arrangement. The ways of seat selecting can be counted as a tactic of students' class behaviors against or for the teacher's powers. Generally, those students who want to listen prefer to choose the middle 3 rows of seats, which can facilitate clear listening to and communication with teachers. They don't fear teacher's gaze, for they can focus attention on learning and regard the gaze or questioning as a kind of care and concern over them. Behind the 3 rows, there is a "failure crack" with 2 to 3 rows left vacant, which is also within the reach of easy watch of teachers. It shows there is no transition area where students who are willing to listening attentively. So they won't choose the seats in the "crack zone". In the meantime, the "failure crack" can be seen as the protective screen for the seated-behind students' everyday life behaviors. In the most cases, the last several rows can be filled, which are closest to the behind door and farthest from the teacher. These strategic seats are favorites for those uwho choose to do their own business instead of listening because they can provide guerrilla 
positioning to slip away from classroom without being detected by the teacher sometimes. The seats are rushed and snagged by the first arrival students. Then, the seats on the left and right can also be filled gradually starting from the behind. Usually, the last arrival students have to be forced to choose the front part of left and right seats. These two zones can be within teachers' secondary attention by side gazing apart from the middle first 3 rows. Choosing whom to sit with can also play an essential role in seat selecting to conduct every life behaviors. In this way, a classroom turns into a socializing place besides learning place. More often than not, they chat with their classmates in private in English class. Also they sit together to gather group power in defense of their rights of chatting personally against the teacher psychologically and practically at times. Therefore, the overall distribution of students' sitting takes the shape of clusters, together with a few detached stars. Some students prefer sitting alone to keep their own independent learning and avoid some interferences from classmates and teachers because they usually choose to study in their own interest regardless of other students and the teacher. Till now, we can draw a seats scatter gram roughly shown as the following:

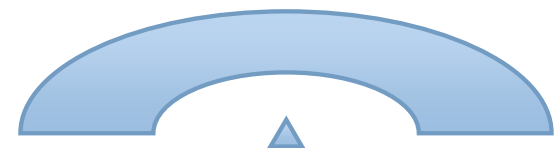

The little triangle stands for the position of teachers and the bow bar is mainly filled by students. In sum, the students' seat selection reflects the gazing power of the teacher and the students try their best to meet or avoid such gazing. They select seats tactically to have their everyday life behaviors such as chatting, eating, playing mobile phones or studying on their own. In addition, such a seat selecting tactic is closely in connection with the temporal performances.

\section{Temporal Performances}

On the regular basis, the students in first middle 3 rows come earlier. They prepare their assignment and questions for enquiry before class, and they usually leave the classroom later because they want more communications with the teacher for more knowledge. Additionally, several rows of seats in the back of the classroom can be filled quickly. They come early mainly for the strategic positions to shield themselves from the gazing or disturbing of the teacher. They can also take advantage of teachers' absence of mind to slip away from the back door after the first class. In this way, the class time can be shortened. The last arrival students are usually forced to find their seats on the left and right side in the front as mentioned above. They are late for class so as to reduce the time in class. Sometimes, they will bargain with the teacher to dismiss them earlier when the time comes near the end of the class. In a word, for those English learners, they try to prolong in-class time. Nonetheless, for non-English learners, they try all means to reduce in-class time or replace English learning with other activities. The activities can fall into two categories. Most students kill or waste time by chatting, sleeping, using mobile phone to see movie or scanning websites and even eating junk food; others try to utilize the time to study their own major or read other books for tests such as driving license. Only a few students choose to listen; most students try a variety of tactics to reduce in class time, to kill time or to use the time by learning other knowledge. All the everyday life behaviors are naturalized and legalized by students' tactical counter-power against teachers' interferences. Therefore, very bad impacts can be brought by students' everyday life behaviors.

\section{Influencing Ranges}

The everyday life behavior is a kind of for-self and by-self reproductive activity. Just as Agnes Heller put it: "we may define everyday life as the aggregate of those individual reproduction factors...”[1] The everyday life behaviors in English class are usually carried out in private secret to 
avoid teachers' attention or discovery. Sometimes they even develop into a sort of open behavior when they become powerful enough to contend against the teachers. So the everyday life behaviors have a negative impact on teachers. The teachers' active enthusiasm of lecturing can be brought down in a seemingly imperceptible way. To a large extent, their lectures are totally ignored by most students. Nevertheless, the teachers can neither stimulate students' interests in English learning nor force their attention to the study because most students have poor basis of English in middle school while a few are better. The result may be that the teachers can teach only the first middle 3 rows. The class order is out of hand. Another bad influence can be the involvement of some English learners into everyday life behaviors by their classmates. These two impacts can be called ink-dye effect. Lastly, the environment of the classroom is seriously polluted by rubbish left by students who eat their junk food and breakfast in class. For this reason, some department put up a notice to prohibit any student from carrying breakfast food into classroom; some departments even have students standing in the entrance to check if any food is carried; school dustmen come to classrooms to ask students not bring any food in. To conclude, students' everyday life behaviors have disturbed class teaching regulation, influencing other students' learning and polluting the classroom.

\section{Theoretical Implications}

In terms of everyday life theoretical arguments, Michel de Certeau[2] tends to regard everyday life behaviors (individualized consumption and use of commodities etc) as a kind of tactics or strategies with which "normal persons" resist the alienation forces from the outside though he hasn't given a clear definition of everyday life. Almost along the same thinking route, Henri Lefebvre gives a more detailed account of everyday life: “...everyday life was an underdeveloped sector compared to technology and production, and moreover that in the mid 20th century, capitalism changed such that everyday life was to be colonized-turned into a zone of sheer consumption.” [3] Everyday life is the natural zone colonized or alienated by outer influences. In Agnes Heller's words, it is a kind of natural reproduction of individuals by itself and for itself. Erving Goffman [4] turns his attention to the presentation of self in everyday life, claiming that everyday behaviors are bound by the region where they occur. Nonetheless, the everyday life behavior in my college English class is a process of legitimatizing through a variety of tactics or strategies against the teacher's power. It may develop into a willful habitus. The practice of such everyday life is organized unconsciously to undermine the school institutions rather than resist the colonization or alienation.

\section{References}

[1]Heller, Agnes, Everyday Life,first ed. Routledge and Kegan Paul, London, 1984:3

[2] de Certeau, Michel, The Practice of Everyday Life, first ed., Nanjing University Press, Nanjing, 2015: 89-99.

[3] Information on https://en.wikipedia.org/wiki/Henri_Lefebvre\#The_critique_of_everyday_life [4]Goffman, Erving, The Presentation of Self in Everyday Life, first ed. University of Edinburg Social Sciences Centre, Edinburg,1956: 66

Sponsor: Innovative team building program of Nanchang Normal College. No. NSTD20143003. 